\title{
Identification by SNP Analysis of a Major Role for Cayetana Blanca in the Genetic Network of Iberian Peninsula Grapevine Varieties
}

\author{
Lalla Hasna Zinelabidine, ${ }^{1,2}$ Abdelmajid Haddioui, ${ }^{2}$ Virginia Rodríguez, ${ }^{3}$ Félix \\ Cabello, ${ }^{4}$ José E. Eiras-Dias, ${ }^{5}$ José Miguel Martínez Zapater, ${ }^{1,3}$ and Javier Ibáñez ${ }^{1 *}$
}

\begin{abstract}
Cayetana Blanca is a grapevine variety widely distributed in the Iberian Peninsula (Spain and Portugal). Its numerous synonyms and its presence in northern Africa point to a long history of cultivation. The goal here was to identify the genetic relationships of Cayetana Blanca with other Iberian and Mediterranean cultivars using a panel of SNP markers. A total of 243 single nucleotide polymorphisms (SNPs) and four chloroplast microsatellite loci allowed for identifying synonyms and trio (parents and offspring) and duo (parent-offspring) relationships. Six trios including Cayetana Blanca as a parent were found and supported by very high LODs. Five of the trios had the variety Alfrocheiro Preto as the other parent and gave rise to cultivars used in Portugal: Cornifesto, Camarate, Mouratón, Malvasia Preta, and Periquita. The Spanish cultivar Jaén Tinto is confirmed to be an offspring of Cayetana Blanca and Listán Prieto. Additionally, synonyms and duos were detected that, in some cases, were not anticipated. The parents of Cayetana Blanca remain unknown, while the geographical origin of Cayetana Blanca could be a border region between Portugal and Spain. Results show that this cultivar has had a relevant impact in the viticulture of that area. As in other European regions, viticulture in the Iberian Peninsula is also marked by the impact of certain varieties that have worked as progenitors of many present cultivars. The results also show the interconnection between Portuguese and Spanish viticulture. Finally, the study demonstrates that SNP is a powerful tool for parentage inference in grapevine.
\end{abstract}

Key words: genetic relationships, historical genetics, parentage analysis, single nucleotide polymorphism, Vitis vinifera

Cayetana Blanca is the prime name of a well-known variety, cultivated in the Iberian Peninsula and the Maghreb region. In the Vitis International Variety Catalogue (VIVC, www.vivc. de) the cultivar appears with 65 synonyms, including Jaén Blanco, the most extended name in Spain, where this variety

'Instituto de Ciencias de la Vid y del Vino (CSIC-Universidad de La RiojaGobierno de La Rioja), Complejo Científico Tecnológico, C/Madre de Dios 51, 26006 Logroño, Spain; ${ }^{2}$ Laboratoire de Gestion et Valorisation des Ressources Naturelles, Equipe de Génétique et Biotechnologie Végétale, Faculté des Sciences et Techniques, Université Sultan Moulay Slimane, Béni Mellal, Morocco; ${ }^{3}$ Dpto. de Genética Molecular de Plantas, Centro Nacional de Biotecnología, CSIC, C/Darwin 3, 28049, Madrid, Spain; ${ }^{4}$ Instituto Madrileño de Investigación y Desarrollo Rural, Agrario y Alimentario, Finca El Encín, Ctra A2, Km 38.200, 28800 Alcalá de Henares, Madrid, Spain; and ${ }^{5}$ Instituto Nacional de Recursos Biológicos, INIA-Dois Portos, Quinta d'Almoinha, 2565-191 Dois Portos, Portugal.

*Corresponding author (email: javier.ibanez@icvv.es; fax: +34 941299 608) Acknowledgments: L.H. Zinelabidine was supported by a fellowship from Agencia Española de Cooperación Internacional (AECI). This work was partially funded by an international research agreement between Genoma España and Genome Canada and by the EUI2008-03752 grant from the MICINN (Spain). The authors thank Mark Thomas (CSIRO) for access to unpublished SNP marker information, José A. Cabezas for the collection of plant materials, Gema Bravo for technical assistance, and Cheo Machín for assistance in the initial editing of the manuscript.

Supplemental data is freely available with the online version of this article at www.ajevonline.org.

Manuscript submitted Jun 2011, revised Sept 2011, accepted Oct 2011

Copyright $(\subseteq 2012$ by the American Society for Enology and Viticulture. All rights reserved.

doi: 10.5344/ajev.2011.11052 is traditionally considered to have a local origin. Jaén was first cited in the 16th century (Herrera 1513) and described as a grape cultivar with large and compact bunches, large berries, and tender skins. The cultivar was widespread, giving rise to great confusion because of many synonyms and homonyms, as recorded in 1807: "El primero que dé á conocer con exâctitud todos los vidueños que se llaman Jaenes en España hará á su patria un servicio real" ["The first person to clarify exactly all cultivars that are called Jaén in Spain will make their country a royal service"] (Rojas Clemente y Rubio 1807). Present synonyms in Spain include Baladí, Baladí Verdejo, Balay (in Cordoba province), Blanca Cayetana, Pardina (Badajoz), Cagazal (La Rioja), Calagraño (La Rioja), Cayetana (Cáceres), Cirial (Jaén), Jainas (La Rioja), Maizancho (Ciudad Real), and Robal (Zaragoza). The cultivated surface for Cayetana Blanca has diminished in Spain from 71,709 ha in 1990 to 45,580 ha in 2007 (Inventario del Potencial Vitícola Campaña 2008/2009. MARM). However, it is still ranked as the sixth most planted cultivar, primarily in the central and south-southwestern regions of the Iberian Peninsula (Extremadura, Andalucía, Castilla-La Mancha, and Madrid).

The existence of synonyms and homonyms for a given cultivar makes it difficult to determine its correct identity and parentage. DNA markers and morphological markers help to identify synonyms and homonyms and to determine the genetic relationships between cultivars (This et al. 2006). Microsatellite or SSR markers have been used in pedigree studies of grape cultivars. Parentage analysis using 30 microsatellites allowed the identification of Cabernet franc and 
Sauvignon blanc as the parents of Cabernet Sauvignon (Bowers and Meredith 1997). Based on 32 loci SSR, Bowers et al. (1999) demonstrated that crosses between Pinot and Gouais Blanc gave rise to Chardonnay and Gamay as well as many other French grapevine cultivars. More recently, 20 polymorphic nuclear and three chloroplast microsatellite loci were used to identify the kinship group of Merlot (Boursiquot et al. 2009). In table grapes, analyses based on 25 nuclear and five chloroplast SSR loci were used to determine the parents of 93 table-grape cultivars (Ibáñez et al. 2009, Vargas et al. 2009).

Cayetana Blanca has been identified as an offspring of a cross between Antão Vaz and Rabo de Ovelha using data obtained for 28 microsatellite loci (Lopes et al. 2006). Although they detected incompatibilities at three loci, the authors argued that the possible existence of null alleles would explain those incompatibilities. The full compatibility at 25 loci, added to the fact that the three varieties are cultivated in a close geographical region (Alentejo in Portugal and Badajoz in Spain), supported the reliability of the suggested cross.

In this study, single nucleotide polymorphisms (SNPs) have been used to establish first-degree genetic relationships among grapevine cultivars. Compared to conventional nuclear SSR, SNPs have several features appropriate for large-scale genetic studies: they are abundant in most genomes surveyed (Brumfield et al. 2003) and they have relatively low costs and the data are very easily scored, allowing a more feasible exchange of data between laboratories. SNPs have been used recently in grapevine for individual identification, integration of genetic and physical maps, and paternity inference (Cabezas et al. 2011, Lijavetzky et al. 2007) and in the study of genetic structure and domestication history of grape (Myles et al. 2011). The power of SNPs for parentage inference has been reported previously (Anderson and Garza 2006), but almost exclusively in animal studies.
Here we present new insights regarding the genetic relationships of Cayetana Blanca through the study of synonyms and several genetically related varieties from the Iberian Peninsula (Spain and Portugal). Altogether, the results identify this cultivar as a major node in the genetic network relating grapevine cultivars in the central region between the two countries.

\section{Materials and Methods}

Plant materials. All accessions studied that are Cayetana Blanca or were found to be closely genetically related to this variety are listed in Table 1. Portuguese and Spanish accessions were sampled from the collection of grapevine varieties of El Encín (IMIDRA, Madrid). The Djinani accession was sampled from the SODEA germplasm bank in Meknes, Morocco. Síria, Sarigo, and Tinta Gorda were obtained from the Colecção Ampelográfica Nacional (CAN) of Instituto Nacional de Investigação Agrária (INIA) in Dois Portos, Portugal. When possible, varieties have been named following the prime names proposed by the Vitis International Variety Catalogue (VIVC, www.vivc.de).

DNA analysis. DNA was isolated from young frozen leaves using the DNeasy Plant Mini Kit (Qiagen, Valencia, CA). Previously identified SNPs (Lijavetzky et al. 2007) were genotyped at the CEGEN (Spanish National Genotyping Centre; www.cegen.org) using SNPlex (Applied Biosystem, Foster City, CA), an application of high-throughput genotyping using a set of universal preoptimized reagents. This system is plex-based and each plex contains 48 markers. Each variety was genotyped using seven plexes (336 SNPs minus four, which were repeated: 332 SNPs), as described in Cabezas et al. (2011). Twenty nuclear microsatellites and four chloroplast microsatellites were also analyzed in some samples through the use of multiplex PCR and run in an Applied Biosystems 310 Genetic Analyzer (Ibáñez et al. 2009).

\begin{tabular}{|c|c|c|c|}
\hline Accession & Country $^{\mathrm{a}}$ & VIVC prime name (number) ${ }^{\mathrm{b}}$ & Synonyms and sports studied \\
\hline Água Santa & $\mathrm{P}$ & Agua Santa (123) & \\
\hline Alfrocheiro & $\mathrm{P}$ & Alfrocheiro Preto (277) & Baboso Negro \\
\hline Antão Vaz & $\mathrm{P}$ & Antao Vaz (493) & \\
\hline Camarate & $\mathrm{P}$ & Camarate Tinto (2018) & \\
\hline Castellana Blanca & $\mathrm{S}$ & Castellana Blanca (40016) & \\
\hline Castillo de Arcos & $S$ & Castillo de Arcos (2328) & \\
\hline Cigüente & $\mathrm{P}, \mathrm{S}$ & Dona Blanca (15673) & Valenciana, Síria \\
\hline Cornifesto & $P$ & Cornifesto (2846) & \\
\hline Criolla & S & Mission (7873) & Listán Prieto, Mission \\
\hline Garrido Macho & S & Garrido Macho (4471) & \\
\hline Jaén & $M, P, S$ & Cayetana Blanca (5648) & Djinani, Morisca, Jaén Rosado, Sarigo \\
\hline Jaén Tinto & $\mathrm{S}$ & Jaen Negro (5652) & \\
\hline Moreto do Dao & $\mathrm{P}$ & Malvasia Preta (15647) & \\
\hline Mouraton & $\mathrm{P}, \mathrm{S}$ & Mouraton (8082) & Tinta Gorda \\
\hline Periquita & $\mathrm{P}$ & Periquita (9152) & \\
\hline Plateado & $\mathrm{S}$ & Doradilla (3654) & Doradilla \\
\hline Rabo de Ovelha & $\mathrm{P}$ & Rabo de Ovelha (16956) & \\
\hline Rocia & $\mathrm{S}$ & Rocia (40057) & \\
\hline Puerto Alto & $\mathrm{S}$ & Puerto Alto (9619) & \\
\hline
\end{tabular}

aM: Morocco, P: Portugal, S: Spain.

${ }^{\mathrm{b}}$ Prime name and variety number, Vitis International Variety Catalogue, www.vivc.de. 
Parentage analysis. On the basis of SNP profiles, cultivars were analyzed for possible parent-offspring groups using Cervus 3.0 software (Field Genetics, London, UK) (Kalinowski et al. 2007). Analysis was performed with 427 cultivars as candidate parents, from a study that included many Iberian and Maghreb cultivars. LOD scores were obtained taking the natural $\log (\log$ to base e) of the overall likelihood ratios for the parents and offspring trios, as implemented in Cervus 3.0. The probability of paternity exclusion was estimated for all the loci combined. Whenever possible, chlorotypes were used to determine which one of the putative parents was the mother, based on maternal transmission of chloroplasts in grapevine (Arroyo-García et al. 2002, Strefeler et al. 1992).

\section{Results and Discussion}

In a wider study, 838 plants were genotyped, many of them from Spain and Portugal, for 332 SNPs (data not shown). After discarding failed SNPs and samples, nonpolymorphic SNPs, and redundant genotypes, we obtained 427 unique genotypes for 243 SNPs. The set of cultivars included several parents and offspring trios previously described using microsatellites (Bowers et al. 1999, Cabezas et al. 2003, Ibáñez et al. 2009, Vargas et al. 2009), which were used as control in the parentage analysis. These control pedigrees and the corresponding LOD scores, which ranged from 59 to 88 with an average and median of 71, are listed in Supplemental Table 1. Reliabilities of pedigrees based on microsatellites are typically based on cumulative likelihood ratios rather than LOD scores, but in some cases both are published, allowing for comparison of SSRs and SNPs. A recent publication showed eight pedigrees involving important French cultivars such as Merlot or Cot (Boursiquot et al. 2009); LOD scores based on 20 SSR ranged from 18 to 50 with an average of 37 and a median of 42 , much lower than those obtained with 243 SNPs in the present study.

From all the detected first-degree relationships, we selected those which could be directly related with Cayetana Blanca: the possible trios (parents and offspring) where one of the varieties involved was Cayetana Blanca; the putative descents of these offspring cultivars; and all cultivars that share at least one allele per locus with Cayetana Blanca and, therefore, maintain a putative parent-offspring relationship (Table 1). Most are presently cultivated either in Spain or Portugal or in both countries. In total, they account for $\sim 50,000$ ha in Spain and 40,000 ha in Portugal, or $5 \%$ and $16 \%$ of total countrywide vineyard surface, respectively. Among these, Cayetana Blanca $(45,580 \mathrm{ha})$ is the most cultivated variety in Spain and Periquita (20,500 ha) and Cigüente (11,700 ha) are the most cultivated in Portugal.

Several Portuguese cultivars are siblings. A total of six trios including Cayetana Blanca as a parent were found (Table 2, Figure 1). Five of them have the same variety as the other parent, a well-known Portuguese variety, Alfrocheiro Preto, which gave place to five varieties presently cultivated in Portugal: Periquita, Cornifesto, Malvasia Preta, Mouraton, and Camarate (Figure 2). These cultivars have been described by Galet (2000) and have different names (synonyms) in different locations of Portugal and/or Spain (Supplemental Table 2).

Alfrocheiro Preto is a red grape, one of the most widely planted (220 ha) in the Dão region (Portugal), and also found in the vineyards of Alentejo, Ribatejo, and Bairrada. Periquita (its current Portuguese name is Castelão) is a red wine cultivar known in Terras do Sado and throughout southern Portugal. Wine produced from this grape is usually quite tannic and fruity. Cornifesto is a black grapevine cultivar planted in the Douro and Alto Trás-os-Montes regions in northern Portugal. Malvasia Preta is an autochthonous red winegrape from the Douro and Dão regions (Portugal) and is also known as Moreto do Dão. The cross originating this variety, under the

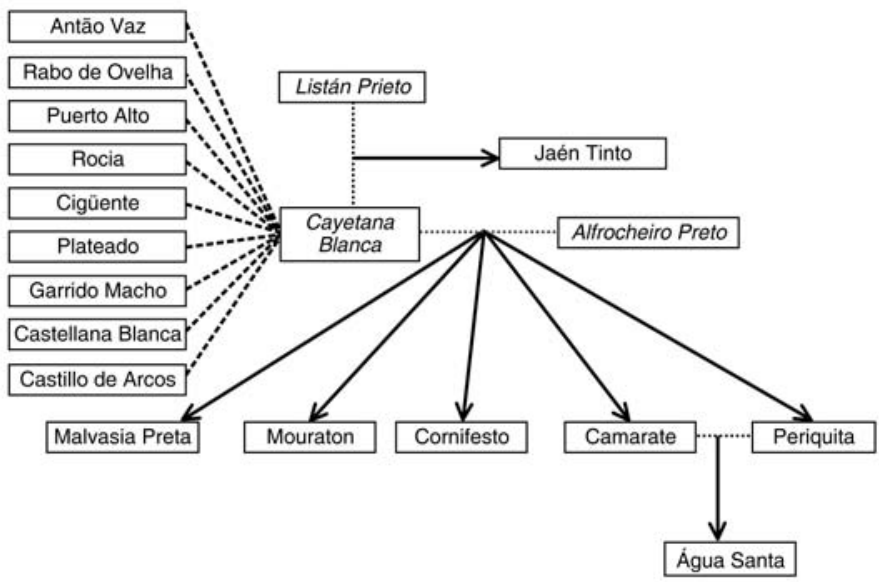

Figure 1 Genetic relationships found for Cayetana Blanca. Solid lines indicate full pedigree (trio parents and offspring), while dashed lines link cultivars sharing at least one allele per locus (possible parent-offspring relationship).

Table 2 Summary of the trios (parents and offspring) found in a parentage analysis of cultivars from Morocco and the Iberian Peninsula, where Cayetana Blanca or its descents were involved.

\begin{tabular}{|c|c|c|c|c|c|c|c|}
\hline Offspring & $\mathbf{H}^{\mathrm{a}}$ & Parent 1 & $\mathbf{H}^{\mathrm{a}}$ & Parent 2 & $\mathbf{H}^{\mathrm{a}}$ & $\begin{array}{c}\text { SNP } \\
\text { compared (n) }\end{array}$ & LOD $^{\mathrm{b}}$ \\
\hline Jaén Tinto & $\mathrm{D}$ & Listán Prieto & $\mathrm{D}$ & Cayetana Blanca & $A$ & 220 & 80 \\
\hline Malvasia Preta & $A$ & Cayetana Blanca & A & Alfrocheiro Preto & $A$ & 235 & 78 \\
\hline Mouraton & A & Cayetana Blanca & $A$ & Alfrocheiro Preto & $A$ & 233 & 76.1 \\
\hline Cornifesto & A & Cayetana Blanca & $A$ & Alfrocheiro Preto & $A$ & 232 & 62.9 \\
\hline Camarate & $A$ & Cayetana Blanca & A & Alfrocheiro Preto & $A$ & 232 & 69.2 \\
\hline Periquita & A & Cayetana Blanca & $A$ & Alfrocheiro Preto & A & 234 & 75.3 \\
\hline Água Santa & A & Camarate & $A$ & Periquita & $A$ & 232 & 81.3 \\
\hline
\end{tabular}

aH: Haplotype for parent and progeny.

bLOD: LOD score of candidate parent, the most likely candidate parent is the one with the highest LOD score. 
name of Mureto, has been described (Lacombe et al. 2007). This variety has a rose mutation. Mouraton is a black Spanish grapevine mainly cultivated in the border between Spain and northeastern Portugal (Arribes del Duero). Tinta Gorda is a Portuguese variety cultivated in Dão and Douro. In this study, a full match has been obtained between the SNP genotypes of this variety and Mouraton, which has allowed for discovering that these two varieties are synonyms. Camarate, a black cultivar widely cultivated in Portugal, was largely planted during the 18th century and presently covers 947 ha (Galet 2000). This variety is characterized by small to medium bunches and is very susceptible to oidium disease. Água Santa is a black winegrape cultivar authorized in the Beira Litoral, Beira Interior, Ribatejo, Madeira, and Açores regions in Portugal. This variety was obtained by Leão Ferreira de Almeida in 1948, after crossing Mortágua (syn. Camarate) and João Santarém (syn. Castelão) (Ghira et al. 1982). SNP data confirmed that this variety originated from a cross between Periquita (syn. Castelão) and Camarate, and thus is a "double grandchild" of Cayetana Blanca and Alfrocheiro Preto (Figure 1).

Jaén Tinto is a descent of Jaén Blanco and Listán Prieto. A cross between the cultivars Cayetana Blanca and Listán Prieto gave rise to Jaén Tinto (Table 2, Figure 1). This cross had been previously described (This et al. 2006) based on the genotypes for 20 microsatellite loci, with a very high LOD score of 61. Using SNP, this trio is supported with an even higher LOD score of 80 . Jaén Tinto is an old Spanish cultivar (Valcarcel 1765, Rojas Clemente 1807, Abela 1885, García de los Salmones 1914) that is now cultivated in southern Spain (Galet 2000), with 1.145 ha in the Granada, Jaén, Almeria, and Badajoz provinces (Figure 2).

There is another red variety called Jaen that originates from the Bierzo region, Castilla-León (Spain) (Martins et al. 1997). This Jaen is a homonym for Jaén Tinto, which corresponds to a synonym of Mencía, the typical red variety of that region.

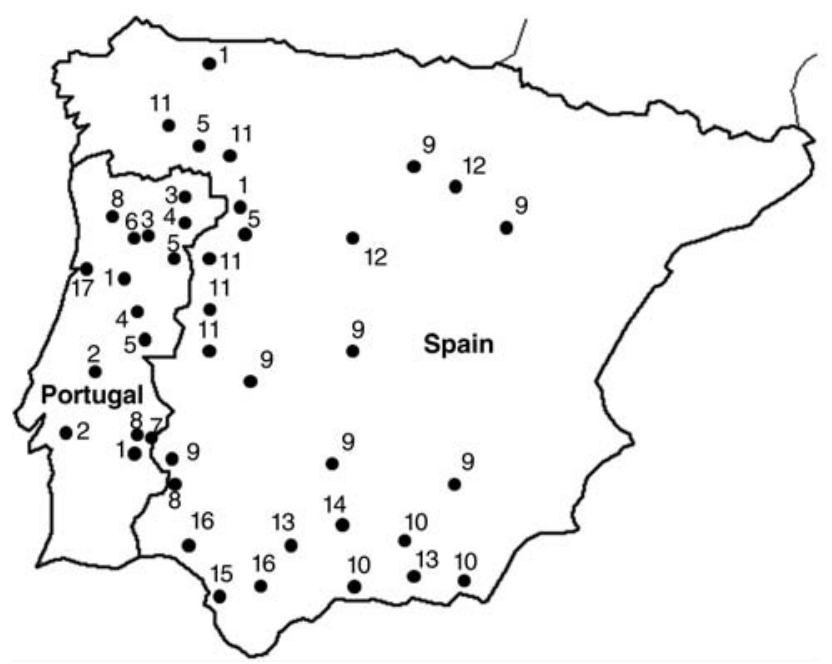

Figure 2 Map of the Iberian Peninsula showing the different locations of the offspring and other cultivars related to Cayetana Blanca: (1) Alfrocheiro Preto, (2) Periquita, (3) Cornifesto, (4) Malvasia Preta, (5) Mouraton, (6) Camarate, (7) Antão Vaz, (8) Rabo de Ovelha, (9) Cayetana Blanca, (10) Jaén Tinto, (11) Cigüente, (12) Castellana Blanca, (13) Plateado, (14) Puerto Alto, (15) Rocia, (16) Castillo de Arcos, (17) Água Santa.
The relationship between Cayetana Blanca and Jaén Tinto was also expected, based on several morphological traits. The shape of the mature leaves is highly similar: pentagonal, with rectilinear teeth, and often a tooth in the margin of the petiole sinus. The clusters of the two cultivars are similar only in shape and density: Jaén Tinto clusters are smaller than those of Cayetana Blanca. Morphological similarities between Jaén Tinto and Cayetana Blanca are exemplified by the fact that a well-known Spanish synonym for Cayetana Blanca is Jaén Blanco. Conversely, Listán Prieto and Jaén Tinto are morphologically quite dissimilar.

There are doubts about the origin of Listán Prieto, and the fact that it is the parent of Jaén Tinto could provide information. Listán Prieto is presently cultivated in several of the $\mathrm{Ca}$ nary Islands, with $\sim 1700$ ha in Tenerife, Lanzarote, and Gran Canaria, but its cultivation in the Iberian Peninsula almost disappeared after phylloxera in the 19th century. This variety is also cultivated in the Americas from California to Chile, where it is known under many names, including País, Criolla, and Mission (Milla-Tapia et al. 2007, This et al. 2006). Some bibliographic sources consider Listán Prieto as originally from the Americas (VIVC), with the suggestion that it could have been developed in South America from grapevine seeds introduced by Spanish missionaries in the 16th century (Galet 1957). Nevertheless, given that Listán Prieto is a parent of Jaén Tinto, a variety mentioned by Valcarcel (1765), indicates its existence as a cultivar earlier in the Iberian Peninsula. Thus, it would be very difficult to consider that Listán Prieto was developed in America from a seed, was multiplied and distributed there, and later brought to the Iberian Peninsula and crossed with Cayetana Blanca to produce Jaén Tinto. In addition, Herrera (1513) cited a variety called Palomino Negro that, according to his description, could possibly correspond to Listán Prieto.

Based on the maternal transmissions of chloroplasts in the Vitis genus (Arroyo-García et al. 2002, Strefeler et al. 1992), the analysis of the chloroplast microsatellite loci leads us to propose Listán Prieto as the mother and Cayetana Blanca as the father of Jaén Tinto. For the other crosses, the coincidence of the parental haplotypes precludes the identification of maternal and paternal parents (Table 2).

Cayetana Blanca is the putative parent of several other Iberian varieties. Cayetana Blanca is related to several Spanish varieties_-Puerto Alto, Castellana Blanca, Cigüente, Plateado, Rocia, Garrido Macho, and Castillo de Arcossharing at least one allele per locus at the 243 SNPs studied (Figure 1). These results point to possible parent-offspring relationships between Cayetana Blanca and each of the mentioned varieties. In some cases this relationship is in agreement with some degree of morphological similarity between the related cultivars, while in others there are no conspicuous similarities.

Puerto Alto is a minor white winegrape cultivar grown in the Andalusian region (southern Spain) (García de los Salmones 1914). Castellana Blanca originated from the Rueda region (Spain) and is also known as Tolociriana and Temprana Agosteña (Yuste et al. 2006). Cigüente is considered a 
Spanish autochthonous cultivar and was first cited by Herrera (1513). This variety spread and is still cultivated along the Spanish-Portuguese border, following the Roman pathway known as Vía de la Plata ("silver way") (Muñoz-Organero et al. 2006), where it is known by various names (Supplemental Table 2). In Portugal, its official name is Síria. Plateado is a white wine grapevine cultivated in Andalusia and first described by Candela (1971). Morphologically it is very similar to Cayetana Blanca. Rocia is a black wine cultivar from Spain also found in southern Spain (Martín et al. 2003). Garrido Macho is a white grapevine, long cultivated in Huelva (a southwestern Spanish region that borders Portugal), from where it spread to Cadiz and neighboring regions (Galet 2000). It is also known as Garrio Macho, Parron Garrido, and Parron Garrio (www.vivc.de). Castillo de Arcos is a white grape cultivated in Jerez, southwest Spain (www.vivc.de).

Origin and synonyms of Cayetana Blanca. AlentejoBadajoz, a region in the southwest Iberian Peninsula, has been suggested as the probable place of origin of Cayetana Blanca (Lopes et al. 2006). In Morocco, the name for Cayetana Blanca is Djinani and is also considered a local variety. Unfortunately, there were no written records on viticulture in Morocco until the 1950s (Vidal 1951). Galet (2000) mentioned Djiniani as a Moroccan variety considered by Truel as a synonym of Jaén Blanco. The accession used here was from the SODEA germplasm bank, a collection created in 1952 in Meknes by Vidal, who collected local vines from different regions, particularly from the Rif (northern Morocco). A comparison of the genetic profile of Djinani and Jaén using 20 SSR recently confirmed that they are synonyms (El Oualkadi et al. 2009). This study confirmed the identity of these synonyms and two color sports (rose) (Table 1) for the SNP markers used. Their local names and distribution are shown in Supplemental Table 2.

In Portugal, Cayetana Blanca is currently known as Sarigo and is cultivated in Douro. It is also known as Mourisco Branco (Alentejo), Boal Carrasquenho, and Dona Branca (Estremadura, Portugal).

The numerous Iberian cultivars identified here as progenies of Cayetana Blanca and the number of synonyms in Spain-Calagraño, Baladí, Blanca Cayetana, Cirial, Baladí Verdejo, Jaén Empinadillo, Maizancho, Robal, Balay, and Cayetana (Asensio 2000, Manso de Zúñiga 1905) — strongly suggest that Cayetana Blanca originated in the Iberian Peninsula, probably close to the present border between Portugal and Spain, where many relatives of Cayetana Blanca have originated and have been long cultivated (Figure 2). The probable exchange of grapevine cultivars between northern Africa and the Iberian Peninsula during centuries of close interaction would be responsible for its spread in Morocco.

The parents of Cayetana Blanca remain unknown. Twenty-eight SSR markers were used to provide evidence that Cayetana Blanca was the progeny of a cross between Antão Vaz and Rabo de Ovelha (Lopes et al. 2006). Although Cayetana Blanca displayed only one of the parental alleles at three loci, the authors posited the presence of null alleles which would still make the cross feasible. Geographical and histori- cal reasons also supported the parentage hypothesis: Antão Vaz is the most important wine white cultivar cultivated in the Alentejo region, around Virgueira, Portugal (Almadanim et al. 2007, Lopes et al. 2006). Rabo de Ovelha is a white grapevine which at present is found throughout Portugal (Lopes et al. 2006), but it probably originated from the Alentejo region (Almadanim et al. 2007). Cayetana Blanca is mainly cultivated in the Extremadura region, close to the Alentejo region, but on the Spanish side of the Iberian Peninsula.

The analysis of 243 SNP loci in Cayetana Blanca, Antão Vaz, and Rabo de Ovelha allowed for discarding the suggested trio because there were incompatibilities at 10 SNPs (Supplemental Table 3). Mutation rates are in general considerably lower for SNPs than for microsatellites (Helyar et al. 2011), and thus it is expected to find fewer incompatibilities due to mutations in parentage analyses using SNP markers than microsatellite markers. In order to definitively corroborate or discard this putative parentage, we genotyped the three cultivars involved at 20 SSR loci. The trio was noncompatible at three SSR loci (Supplemental Table 4): VMC1B11, VVIQ52, and VVMD32. Furthermore, since Cayetana Blanca is heterozygous at these three mismatching loci, noncompatibilities cannot be caused by null alleles.

We also tested the possibility of pair-wise relationships of parent-offspring type in the three varieties. Antão Vaz and Rabo de Ovelha are not compatible at four SNPs. A similar result was previously found using 28 SSR markers where the two varieties share only $36 \%$ of alleles and then cannot have a parent-offspring relationship (Lopes et al. 2006). Nevertheless, Antão Vaz with Cayetana Blanca and Rabo de Ovelha with Cayetana Blanca share one allele per locus in all markers analyzed in this study. Thus, we conclude that Antão Vaz x Rabo de Ovelha is not the cross that gave rise to Cayetana Blanca; however, one of them could be a parent and the other an offspring, or perhaps both are offspring of Cayetana Blanca. This result stresses the difficulties of rejecting false trios when very closely related cultivars are involved, even using a high number of markers.

As described above, we found that Cayetana Blanca is related to other old and minor cultivars from Spain and Portugal, sharing one allele per locus at 243 SNPs (Figure 1, Figure 2). Any of them could be one of the parents of Cayetana Blanca, but, given the known history of the varieties included, we suggest that Cigüente or Castellana Blanca would be more probable.

\section{Conclusions}

This parentage analysis is one of the first in grapevine based on SNP marker data. SNPs will soon become the marker of choice for parentage analyses, as they are well suited to the high-throughput genotyping required for large studies, genotyping error rates are low, and LOD scores obtained are high, which provides strong support to the pedigrees found. This study sheds light on the genetic relationships among cultivars from Spain and Portugal related to the important cultivar Cayetana Blanca. The number of varieties directly related to Cayetana Blanca highlights its significance as a genetic node 
in the network of pedigrees originating Iberian grapevine varieties. The full parentages of Jaén Tinto, Cornifesto, Camarate, Mouraton, Malvasia Preta, Periquita (Castelão), and Água Santa have been discovered or confirmed, as well as other nine varieties with putative parent-offspring relationship regarding Cayetana Blanca. Genetic and historical data point to the origin of Cayetana Blanca in the southwest Iberian Peninsula, while its parents remain unknown.

\section{Literature Cited}

Abela, E. 1885. El libro del viticultor. (2008) Editorial Maxtor, Madrid.

Almadanim, M.C., M.M. Baleiras-Couto, H.S. Pereira, L.C. Carneiro, P. Fevereiro, J.E. Eiras-Dias, L. Morais-Cecilio, W. Viegas, and M.M. Veloso. 2007. Genetic diversity of the grapevine (Vitis vinifera $\mathrm{L}$.) cultivars most utilized for wine production in Portugal. Vitis 46:116-119.

Anderson, E.C., and J.C. Garza. 2006. The power of single-nucleotide polymorphisms for large-scale parentage inference. Genetics 172: $2567-2582$

Arroyo-García, R., F. Lefort, M.T. de Andrés, J. Ibáñez, J. Borrego, N. Jouve, F. Cabello, and J.M. Martínez-Zapater. 2002. Chloroplast microsatellite polymorphisms in Vitis species. Genome 45:1142-1149.

Asensio, M.L. 2000. Caracterizacion de variedades de Vitis vinifera L. cultivadas en Extremadura, mediante estudios morfológicos, agronómicos y bioquímicos. Universidad Politécnica de Madrid, Madrid.

Boursiquot, J.M., T. Lacombe, V. Laucou, S. Julliard, F.X. Perrin, N. Lanier, D. Legrand, C. Meredith, and P. This. 2009. Parentage of Merlot and related winegrape cultivars of southwestern France: Discovery of the missing link. Aust. J. Grape Wine Res. 15:144-155.

Bowers, J.E., and C.P. Meredith. 1997. The parentage of a classic wine grape, Cabernet Sauvignon. Nat. Genet. 16:84-87.

Bowers, J.E., J.M. Boursiquot, P. This, K. Chu, H. Johansson, and C.P. Meredith. 1999. Historical genetics: The parentage of Chardonnay, Gamay, and other wine grapes of northeastern France. Science 285:1562-1565

Brumfield, R.T., P. Beerli, D.A. Nickerson, and S.V. Edwards. 2003. The utility of single nucleotide polymorphisms in inferences of population history. Trends Ecol. Evol. 18:249-256.

Cabezas, J.A., M.T. Cervera, R. Arroyo-García, J. Ibáñez, I. Rodríguez-Torres, J. Borrego, F. Cabello, and J.M. Martínez-Zapater. 2003. Garnacha and Garnacha Tintorera: Genetic relationships and the origin of teinturier varieties cultivated in Spain. Am. J. Enol. Vitic. 54:237-245.

Cabezas, J.A., et al. 2011. A 48 SNP set for grapevine cultivar identification. BMC Plant Biol. 11:153.

Candela, M.R. 1971. Contribucion al conocimiento del inventario viticola nacional. INIA, Madrid.

El Oualkadi, A., M. Ater, Z. Messaoudi, V. Laucou, J.M. Boursiquot, T. Lacombe, and P. This. 2009. Molecular characterization of Moroccan grapevine germplasm using SSR markers for the establishment of a reference collection. J. Int. Sci. Vigne Vin. 43:135-148.

Galet, P. 1957. Cépages et vignobles de France: précis d' ampelographie pratique. Le Paysan du Midi, France.

Galet, P. 2000. Dictionnaire Encyclopédique des Cépages. Hachette, Paris.

García de los Salmones, N. 1914. Memoria General de las Sesiones del Congreso y Ponencias presentadas. Imprenta provincial, Pamplona.

Ghira, J.C., L.C. Carneiro, H.P. Carvalho, I.S. Garcia, and J.S. Vinagre. 1982. Estudo Vitícola e Enológico de Castas Novas da EAN. D.G. Extensão Rural, Lisbon.
Helyar, S.J., et al. 2011. Application of SNPs for population genetics of nonmodel organisms: New opportunities and challenges. Mol. Ecol. Resources 11:123-136.

de Herrera, A. 1513. Agricultura General. Edición facsimil (1981). Servicio de Publicaciones del Ministerio de Agricultura y Pesca, Madrid.

Ibáñez, J., A.M. Vargas, M. Palancar, J. Borrego, and M.T. de Andrés. 2009. Genetic relationships among table-grape varieties. Am. J. Enol. Vitic. 60:35-42.

Kalinowski, S.T., M.L. Taper, and T.C. Marshall. 2007. Revising how the computer program CERVUS accommodates genotyping error increases success in paternity assignment. Mol. Ecol. 16:1099-1106.

Lacombe, T., J.M. Boursiquot, V. Laucou, F. Dechesne, D. Varès, and P. This. 2007. Relationships and genetic diversity within the accessions related to Malvasia held in the Domaine de Vassal grape germplasm repository. Am. J. Enol. Vitic. 58:124-131.

Lijavetzky, D., J.A. Cabezas, A. Ibáñez, V. Rodriguez, and J.M. Martínez-Zapater. 2007. High throughput SNP discovery and genotyping in grapevine (Vitis vinifera $L$.) by combining a re-sequencing approach and SNPlex technology. BMC Genomics 8:424.

Lopes, M.S., M.R. dos Santos, J.E.E. Dias, D. Mendonca, and A.D. Machado. 2006. Discrimination of Portuguese grapevines based on microsatellite markers. J. Biotechnol. 127:34-44.

Manso de Zúñiga, V. 1905. Memoria anual. In Estación Enológica de Haro, pp. 29-64. Haro, La Rioja.

Martín, J.P., J. Borrego, F. Cabello, and J.M. Ortiz. 2003. Characterization of Spanish grapevine cultivar diversity using sequence-tagged microsatellite site markers. Genome 46:10-18

Martins, A., L. Carneiro, V. Pedroso, J. Eiras-Dias, C. Pereira, and A. Almeida. 1997. Nova perspectiva sobre a origem e a natureza genética da Casta Jaen. In 1st Congresso O Dão em debate. Nelas, Portugal.

Milla-Tapia, A., J.A. Cabezas, F. Cabello, T. Lacombe, J.M. MartínezZapater, P. Hinrichsen, and M.T. Cervera. 2007. Determining the Spanish origin of representative ancient American grapevine varieties. Am. J. Enol. Vitic. 58: 242-251.

Muñoz-Organero, G., J. Díaz, I. Rodríguez-Torres, C. Rubio, M.T. Andrés, J. Borrego, J. Ibáñez, and F. Cabello. 2006. La variedad Cigüente y sus sinonimias. Ubicación en la "Vía de la Plata". Vit. Enol. Profesional 102:43-52.

Myles, S., et al. 2011. Genetic structure and domestication history of the grape. Proc. Nat. Acad. Sci. USA 108:3457-3458.

de Rojas Clemente y Rubio, S. 1807. Ensayo sobre las variedades de la vid común que vegetan en Andalucía. Edición facsimil (2002). Junta de Andalucía. Consejería de Agricultura y Pesca, Sevilla.

Strefeler, M.S., N.F. Weeden, and B.I. Reisch. 1992. Inheritance of chloroplast DNA in two full-sib Vitis populations. Vitis 31:183-187.

This, P., T. Lacombe, and M.R. Thomas. 2006. Historical origins and genetic diversity of wine grapes. Trends Genet. 22:511-519.

Valcarcel, J.A. 1765. Agricultura general y gobierno de la Casa de Campo. Joseph Estevan Dolz, Valencia.

Vargas, A.M., M.T. de Andrés, J. Borrego, and J. Ibáñez. 2009. Pedigrees of fifty table-grape cultivars. Am. J. Enol. Vitic. 60:525-532.

Vidal, J.P. 1951. La Vigne au Maroc. Terre Marocaine, Casablanca.

Yuste, J., J.P. Martin, J.A. Rubio, E. Hidalgo, P. Recio, J.C. Santana, C. Arranz, and J.M. Ortiz. 2006. Identification of autochthonous grapevine varieties in the germplasm collection at the ITA of 'Castilla y Leon' in Zamaduenas Station, Valladolid, Spain. Span. J. Agric. Res. 4:31-36. 